\title{
ACID AND PARTIAL OXIDATION REACTIONS ON PHOSPHOROUS-BASED CATALYSTS
}

\section{JACQUES C. VEDRINE}

The Leverhulme Centre for Innovative Catalysis, Department of Chemistry, The University of Liverpool, Oxford Street Liverpool, L69 7ZD, United Kingdom

\begin{abstract}
In this presentation emphasis has been placed on heterogeneous catalysts where phosphorous is a determining element. These correspond to phosphate based materials as vanadyl pyrophosphate used industrially for the oxidation of butane to maleic anhydride in the $630-670 \mathrm{~K}$, iron phosphates and hydrogeno/hydroxyphosphates for the oxidative dehydrogenation $(\mathrm{ODH})$ of isobutyric acid to methacrylic acid in the 650-680K temperature range, zirconium hydrogenophosphates as layered compounds used to stabilise/entrappe catalytically active compounds as $\mathrm{Al}, \mathrm{Zr}$, or $\mathrm{Cr}, \mathrm{V}$ hydroxy or hydroy-oxy macrocations species used in acid-type reactions as alkane cracking or partial oxidation reactions as $\mathrm{ODH}$ of light alkanes, respectively, microporous aluminophosphate molecular sieves (AIPO, MeAPO, ElAPO,...).

It is shown that the catalyst surface behave as a rather dynamic and labile surface, reconstructing under activation and/or catalytic reaction conditions and adapting itself to the stereochemistry of the reactants. In partial oxidation reactions the active sites are shown to have a molecular size and have several catalytic functions. The hydrocarbon molecule is first adsorbed, then activated, some of its hydrogen atoms are extracted while lattice oxygens are incorporated into it and electron transfer did occur through the solid material to allow oxidation reaction mechanism to proceed. The metal $M$ cations are the active species and the role of the phosphate tetrahedra is not only to bind the $\mathrm{MO}_{6}$ octahedra together to constitute a dense or layered compound but also to bring some specific redox and acid-base properties. In the case of microporous phosphates, the active sites are more localised and static, while their chemical (redox and/or acid-base) properties, molecular and spatial structures (porosity inducing shape selectivity) turned out to be the determining factors for their catalytic properties.
\end{abstract}

\section{INTRODUCTION}

Phosphorous is a key element in many catalyst formulations. In homogeneous catalysis phosphine ligands are well known and largely used world wide. In many cases $P$ is used as additive or promoter as in industial formulations with either a chemical or a structural role. In heterogeneous catalysis majority of catalysts containing appreciable amounts of phosphorus can be divided in two classes: (i) one is composed of inorganic phosphates and hydrogeno/hydroxy-phosphates as alumino phosphates used as acid catalyst in the early 60ies or as a support, vanadyl pyrophosphate, zirconium hydrogeno phosphates and iron hydrogeno/hydroxy-or meta-phosphates and (ii) the second one is formed of molecular structures as heteropolyoxometallates (not considered here) and molecular sieves of the $\mathrm{AIPO}_{4}$ family. 
This catalyst is certainly one of the most fascinating materials in the sense that it is able to catalyse selectively several hydrocarbons, whereas usually catalysts are much more specific to a given reaction. Its great interest resides in its ability to oxidise a rather inert alkane as n-butane to maleic anhydride an important intermediate for resins, rather specifically with an industrial yield better than $60 \%$ at $620-650 \mathrm{~K}$. Many reviews have appeared in the last decade about such material (e.g. ref 1), while huge scientific and experimental works have been performed to optimise the preparation, activation and catalytic conditions and to understand its peculiar properties ${ }^{2-10}$. More recently, such a material was also shown to oxidise $\mathrm{n}$-pentane into both maleic and phthalic anhydrides, two very valuable chemicals. It was also shown in presence of water in the feed to even oxidise propane to acrylic acid and, if supported on $\mathrm{TiO}_{2}$ support, to oxidise ethane to acetic acid. Unfortunately, the yields in the acid was too low to any industrial application. However this emphasizes the fascinating catalytic properties if such phosphate material.

The optimal preparation organic route consists in activating in a 1 to $2 \%$ butane in air flow at the reaction temperature the hemihydrate precursor $\left(\mathrm{VOHPO}_{4}, 0.5 \mathrm{H}_{2} \mathrm{O}\right.$, prepared in a solution starting from $\mathrm{V}_{2} \mathrm{O}_{5}$ reduced at reflux in isobutanol). The activated catalyst, designated usually VPO, is majoritarily composed of the vanadyl pyrophosphate phase $\left((\mathrm{VO})_{2} \mathrm{P}_{2} \mathrm{O}_{7}\right)$ as shown by XRD and molecular spectroscopies such as Raman and FT IR), the (100) plane being suggested to be the active and selective plane ${ }^{8-10}$.

However, NMR technique, using the spin echo mapping procedure ${ }^{11}$ $\left(\mathrm{V}^{4+}\right.$ as $\mathrm{d}^{1}$ cation is paramagnetic, which shifts and broadens very strongly the ${ }^{51} \mathrm{~V}$ NMR peak) has permitted to show that the most performing catalysts contained some $\mathrm{V}^{5+}$ cations dispersed on top of the vanadyl pyrophosphate in a way not to create any of the vanadyl orthophosphate $\mathrm{V}^{5+}$ phases $\mathrm{VOPO}_{4}$ known to be detrimental, particularly the beta form. In situ Raman spectroscopy studies, starting from the hemihydrate precursor, have clearly shown ${ }^{12}$ that maleic anhydride was only formed when the precursor was transformed into vanadyl pyrophos phate.

Note that, even if the stoichiometry of the vanadyl pyrophosphate corresponds to $\mathrm{P}: \mathrm{V}=1: 1$, the best industrial catalyst and, subsequently all VPO catalysts, are prepared at present with a chemical stoichiometry larger than 1 (usually $1.2-1.3$ ) in the preparation medium, resulting in a material with a P:V ratio in the range $1.03-1.05$. It was then observed by XPS and LEIS analysis that the actual catalyst surface was enriched in phosphorus with respect to the $\mathrm{P}: \mathrm{V}=1: 1$ ratio by a factor of more than two.

The reaction, shown to proceed via a direct route ${ }^{13}$ following a rattle Mars and van Krevelen mechanism, corresponds to:

$$
\mathrm{CH}_{3}-\mathrm{CH}_{2}-\mathrm{CH}_{2}-\mathrm{CH}_{3}+7\left(\mathrm{O}^{2-}\right)-\cdots-->\mathrm{C}_{4} \mathrm{H}_{2} \mathrm{O}_{3}+4 \mathrm{H}_{2} \mathrm{O}+6 \mathrm{e}^{-}
$$

i.e. necessitates a site able to abstract $8 \underline{\mathrm{H}}$ atoms, incorporate $3 \underline{\mathrm{O}}$ atoms into the n-butane molecule and to permit a 8 electron transfer within the solid to insure the redox Mars and van Krevelen mechanism to occur. This very demanding reaction necessitates a multifunctional site able to fulfill 
all requirements without desorption of the intermediate species. One writes usually:

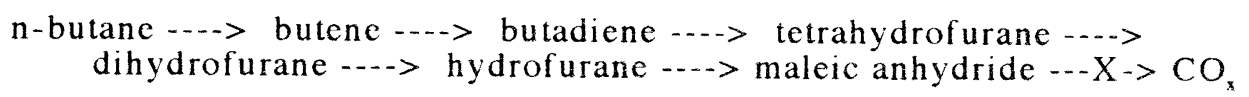

A mechanism proposed by Trifirò and Cavani ${ }^{8}$ is shown in fig. 1, where butane adsorbs on Lewis sites $\left(\mathrm{V}^{4+}\right)$ on a vanadyl dimer of the (100) face of $(\mathrm{VO})_{2} \mathrm{P}_{2} \mathrm{O}_{7}$ and lattice oxygens react with adsorbed butane to give sequentilly tetrahydrofurane, furane and maleic anhydride as in rattle-type Mars and van Krevelen mechanism.

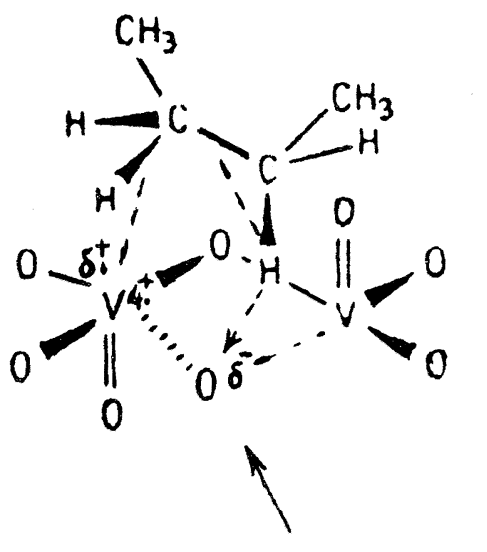<smiles>CC=CC(=O)O[WH](=O)(O)[Y6](=O)(=O)O</smiles>

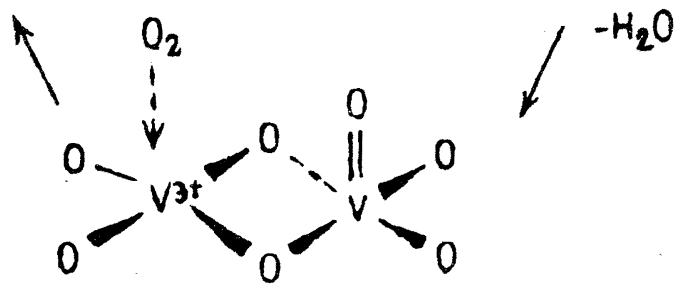

FIGURE 1. Proposed mechanism for the first step of butane oxidation on VPO catalyst taken from ref. 8.

It was further thensuggested ${ }^{14}$ that the surface active sites for such a very demanding reaction are actually composed of four vanadyl dimers (one vanadyl pointing out and one pointing inside the (100) face), separated one from the other by phosphate entities in excess at the surface (see above), as schematised in fig. 2 taken from ref. 14. The dimers are shown by the double squares, the $\mathrm{PO}_{4}$ tetrahedra by the dashed triangles and the excess phosphorus by the dashed triangle filled with $P$. The active sites, composed of four dimers, are represented by the ensembles of arrows and are isolated one from the other by the excess phosphorus, which visualises the surface oxygen diffusion limitation barrier principle. 


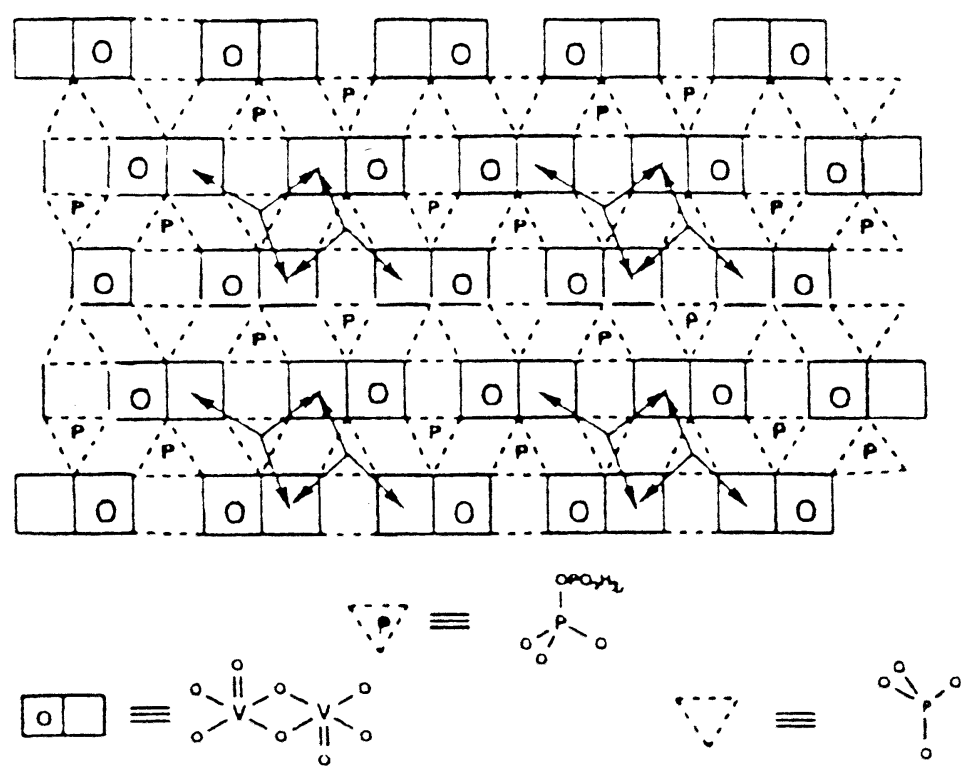

FIGURE 2. Schematic representation of active sites as described in the text above taken from ref. 14.

IR and calorimetric studies have shown that the VPO catalyst contained both strong Brönsted and Lewis acid sites but no basic ones ${ }^{15}$. It is thus very probable that the butane is activated by the acid sites. Moreover, it is also generally accepted that an acid surface is necessary to facilitate the desorption of an acid product as maleic anhydride from the surface and then to avoid deeper oxidation. These requirement is fulfilled by the VPO catalyst. The use of some dopants as Mo, Co, Fe, Zr...in many industrial formulations ${ }^{16}$ is now better understood in terms of morphological modification (favouring the (100) plane) and surface redox, acid base properties and electron transfer features improvements ${ }^{17-20}$ and dynamical surface active sites described at a molecular level.

The concept described above of dynamic catalytic sites at a molecular level has been detailed recently in several reviews ${ }^{21-23}$.

\section{IRON PHOSPHATES AND HYDROXYPHOSPHATES}

Such materials have appeared recently as potential catalysts in the range $650-680 \mathrm{~K}$ for the oxidative dehydrogenation of isobutyric acid (IBA) into methacrylic acid (MAA) according to the reaction:

$$
\left(\mathrm{CH}_{3}\right)_{2} \mathrm{CH}-\mathrm{CO}(\mathrm{OH})+\mathrm{O}^{2-}-\cdots-\left(\mathrm{CH}_{3}\right) \mathrm{CH}_{2}=\mathrm{C}-\mathrm{CO}(\mathrm{OH})+\mathrm{H}_{2} \mathrm{O}+2 \mathrm{e}^{-}
$$

This reaction is used to synthesize an important intermediate for the synthesis of methyl methacrylate, a monomer used for the formation of plexiglass and altuglass polymers.

It has been show $n$ that this reaction proceeded via a Mars and van Krevelen mechanism and that the active phases contain both $\mathrm{Fe}^{2+}$ and $\mathrm{Fe}^{3+}$ 
cations, which ensure the electron transfer necessary for the above mentioned mechanism ${ }^{24.25}$. Actually, all a series of inorganic iron phosphates and hydroxy phosphates, taken within the $\mathrm{FeO}-\mathrm{Fe}_{2} \mathrm{O}_{3}-\mathrm{P}_{2} \mathrm{O}_{5}$ phase diagram and its oxy/hydroxy complement were studied. They exhibited $\mathrm{FeO}_{6}$ octahedra in more or less long polymeric chains, separated one from the other by cationic vacancies and bound between them by $\mathrm{PO}_{4}$ tetrahedra.

It was also shown that for two polymorphic forms, as alpha and beta $\mathrm{Fe}_{2}\left(\mathrm{P}_{2} \mathrm{O}_{7}\right)$ shown in fig. 3 , the former one was quite selective while the other was not. It was then suggested that the way $\mathrm{FeO}_{6}$ octahedra were shared between them was a determining factor. It was shown that the best catalysts contained face sharing $\mathrm{FeO}_{6}$ octahedra trimers. Such an arrangement presumably facilitated the electron hopping between $\mathrm{Fe}^{2+}$ and $\mathrm{Fe}^{3+}$ cations during the catalytic reaction, as it will be discussed below with theoretical calculation data.

a

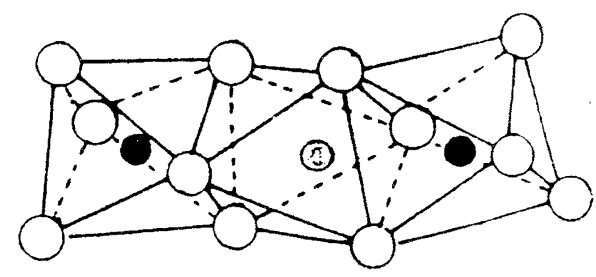

$\mathbf{b}$

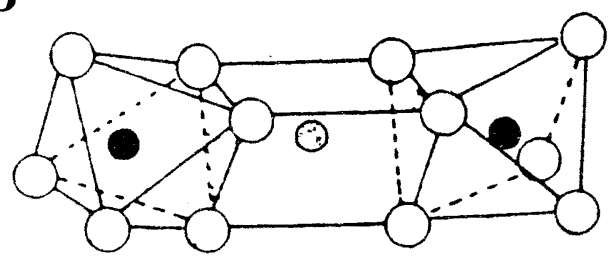

FIGURE 3. Arrangements of $\mathrm{FeO}_{6}$ octahedra in trimeric clusters separated one from the other by pyrophosphate groups: a: alpha b: beta forms of $\mathrm{Fe}_{3}\left(\mathrm{P}_{2} \mathrm{O}_{7}\right)_{2}$; grey circles, $\mathrm{Fe}^{2+}$; black circles, $\mathrm{Fe}^{3+}$

Moreover, in order to improve catalytic activity and, overall to maintain activity by limiting the deactivation with time on stream, it was shown that the use of large amounts of water in the feed was necessary. A typical gas feed composition was: IBA $/ \mathrm{O}_{2} / \mathrm{H}_{2} \mathrm{O} / \mathrm{N}_{2}=6 / 4 / 72 / 18$ $\mathrm{kPa}$. From the whole study, it was suggested ${ }^{26.27}$ that the redox process and the role of water could be represented for a given compound as shown below:

$$
\begin{gathered}
\mathrm{Fe}_{2}{ }^{3+} \mathrm{Fe}^{2+}\left(\mathrm{P}_{2} \mathrm{O}_{7}\right)_{2}+2 \mathrm{H}_{2} \mathrm{O}<\cdots-\mathrm{Fe}_{2}{ }^{3+} \mathrm{Fe}^{2+}\left(\mathrm{PO}_{3} \mathrm{OH}\right)_{4} \\
\mathrm{Fe}_{2}{ }^{3+} \mathrm{Fe}^{2+}\left(\mathrm{PO}_{3} \mathrm{OH}\right)_{4}+(\mathrm{x} / 4) \mathrm{O}_{2} \cdots>\mathrm{Fe}_{2+\mathrm{x}}{ }^{3+} \mathrm{Fe}_{1-\mathrm{x}}{ }^{2+}\left(\mathrm{PO}_{3} \mathrm{OH}\right)_{4-\mathrm{x}}\left(\mathrm{PO}_{4}\right)_{\mathrm{x}}+ \\
(1 / 2) \mathrm{H}_{2} \mathrm{O}
\end{gathered}
$$


The reaction was then proposed to proceed according to the mechanism schematised below, which involves the abstraction of $2 \underline{H}$ atoms of the IBA molecule by phosphate groups of the catalyst resulting in the formation of hydroxyphosphate groups:

$$
\begin{aligned}
& \mathrm{Fe}_{2+x}{ }^{3+} \mathrm{Fe}_{1-x}{ }^{2+}\left(\mathrm{PO}_{3} \mathrm{OH}\right)_{4-x}\left(\mathrm{PO}_{4}\right)_{x}+\mathrm{yIBA} \\
& \mathrm{Fe}_{2+x-2 y}{ }^{3+} \mathrm{Fe}_{1-x+2 y}{ }^{2+}\left(\mathrm{PO}_{3} \mathrm{OH}\right)_{4-x+2 y}\left(\mathrm{PO}_{4}\right)_{x-2 y}+\mathrm{y} \mathrm{MAA}
\end{aligned}
$$

This redox process was shown to hold true for the whole hydroxyphosphate series, in particular for a same solid solution represented in fig. 4 and of the type:

$$
\mathrm{Fe}_{4-\mathrm{x}}{ }^{3+} \mathrm{Fe}_{3 \mathrm{x}}{ }^{2+}(\mathrm{OH})_{3-3 \mathrm{x}}\left(\mathrm{PO}_{4}\right)_{3} \mathrm{O}_{3 \mathrm{x}} \quad \text { with } 0<\mathrm{x}<1 .
$$

Depending upon their composition these phases contain $\mathrm{FeO}_{6}$ octahedra clusters of different size ranging from dimers as for $\mathrm{Fe}_{4}\left(\mathrm{PO}_{4}\right)_{3}(\mathrm{OH})_{3}$ to continuous chains as for beta- $\mathrm{Fe}_{2}\left(\mathrm{PO}_{4}\right) \mathrm{O}$. The results also showed that all samples were active and selective for the reaction studied, whatever the different sizes of the octahedra chains, but the optimum properties were obtained for the phase $\mathrm{Fe}_{3}\left(\mathrm{PO}_{4}\right)_{2}(\mathrm{OH})_{2}$ called barbosalite and containing trimers of $\mathrm{FeO}_{6}$ octahedra. The role of water was suggested to stabilise the hydroxylated catalysts, which involves $\mathrm{O} / \mathrm{OH}$ and $\mathrm{PO}_{4} / \mathrm{PO}_{3} \mathrm{OH}$ couples.

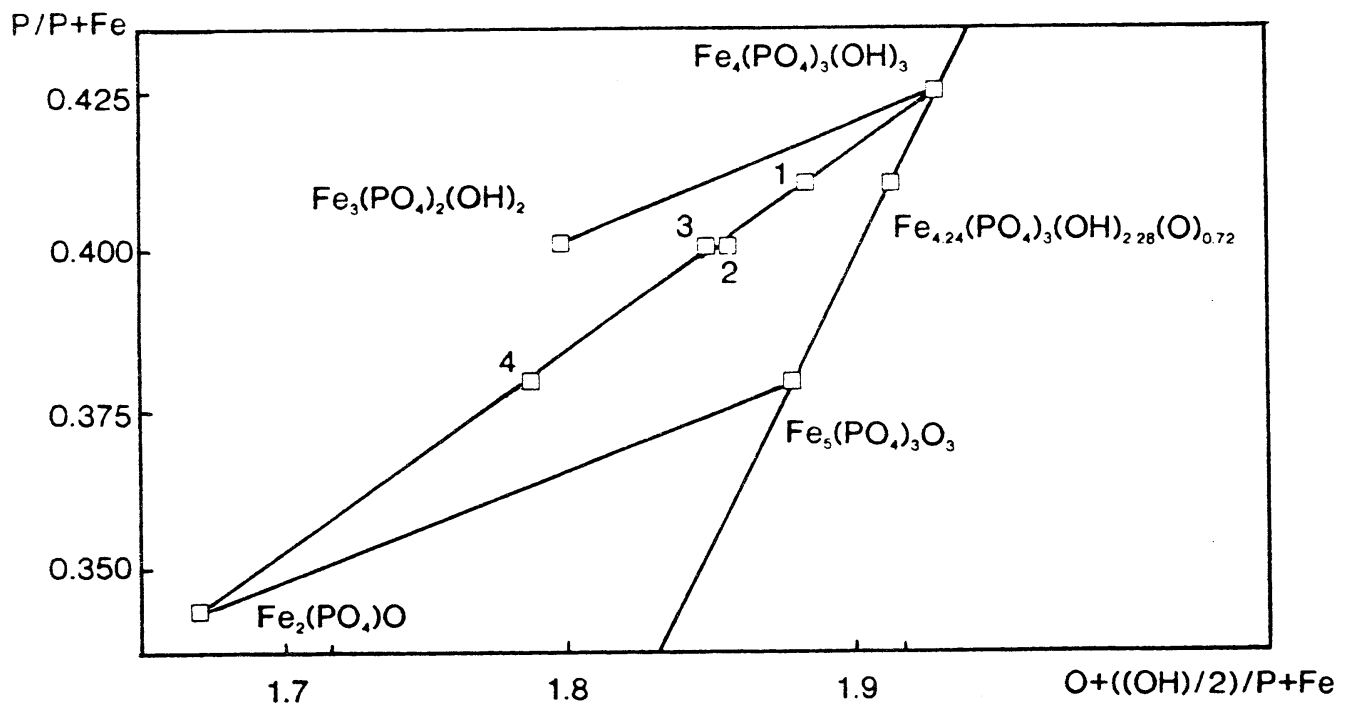

FIGURE 4. Phase diagram of the system $\mathrm{FePO}(\mathrm{OH})$. The numbers 1 to 4 correspond to 1- $\mathrm{Fe}_{4.24}{ }^{3+}\left(\mathrm{PO}_{4}\right)_{3}(\mathrm{OH})_{2.28} \mathrm{O}_{0.72}, \stackrel{2}{=}$ and $\underline{3}-\mathrm{Fe}_{2}{ }^{3+} \mathrm{Fe}^{2+}\left(\mathrm{PO}_{4}\right)_{2}(\mathrm{OH})_{2}$ barbosalite and liscombite and $4-\mathrm{Fe}_{5}{ }^{3+}\left(\mathrm{PO}_{4}\right)_{2} \mathrm{O}_{3}$ 
In a theoretical study using extended Hückel molecular orbital calculations, it was shown that for iron octahedra assembled as dimers ${ }^{28}$, trimers ${ }^{29}$ or larger clusters fast electron exchange may exist between one $\mathrm{Fe}^{2+}$ and a neighbouring $\mathrm{Fe}^{3+}$ cations. This occurs for trimers and some longer chains with face sharing $\mathrm{FeO}_{6}$ octahedra but not at all for dimers nor for trimers in beta- $\mathrm{Fe}_{3}\left(\mathrm{P}_{2} \mathrm{O}_{7}\right)_{2}$ as schematised below in fig. 5 . Note that these calculations were performed uniquely on $\mathrm{FeO}_{6}$ octahedra, i.e. the presence of $\mathrm{PO}_{4}$ tetrahedra was ignored. However, taking catalytic data into account, it was then suggested that this fast electron exchange between Fe cations should first exist but also be limited to the closest neighbours to give the most performant catalyst ${ }^{30}$.
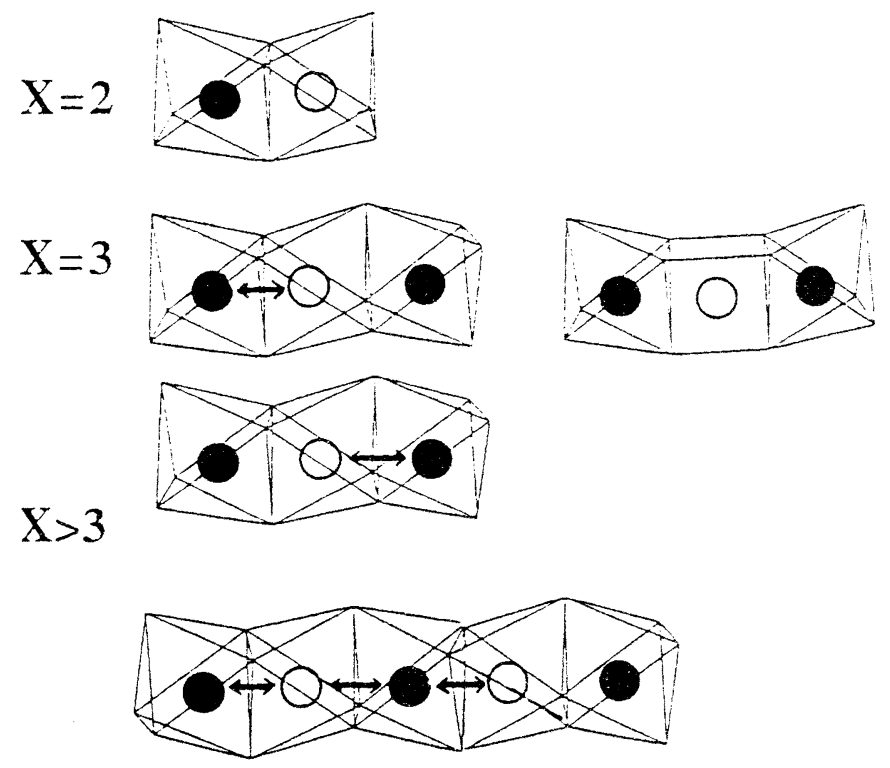

FIGURE 5. Electron hopping between Fe cation in $\left(\mathrm{FeO}_{6}\right)_{\mathrm{x}}$ octahedra clusters calculated by Hückel molecular orbital theory, taken from ref. 28 and 29.

Following the results and calculations described above, it appeared that the role of $\mathrm{PO}_{4}$ octahedra, if any, was rather secondary with respect to that of $\mathrm{FeO}_{6}$ octahedra and water. Some other inorganic materiaks exhibiting $\mathrm{FeO}_{6}$ octahedra in trimer chains were then synthesised or kincly provided by the Natural History Museums in Lyon and Paris. For instance, a natural compound called Ilvaite $\left(\mathrm{CaFe}^{3+} \mathrm{Fe}_{2}{ }^{2+} \mathrm{Si}_{2} \mathrm{O}_{7} \mathrm{OOH}\right)$, where silicate layers replace phosphate anions and $\mathrm{FeO}_{6}$ octahedra forms long chain ribbons, was also studied ${ }^{31}$. It is worth noting that such a material was actually quite active and selective for the ODH of IBA, although to a smaller extent, but much less sensitive to the presence of water in the feed. The lower activity may be assigned to the presence of $\mathrm{Ca}$ cations in the structure which induces some basicity and to silicate anions which are more basic than phosphate anions in the sense of Pearson. We have mentioned above, that this could be detrimental for the desorption of an acid product, as presently MAA. 
In table 1 We have examplified the whole study by a presentation of a selected number of cristalline structures of the $\mathrm{FeO}, \mathrm{Fe}_{2} \mathrm{O}_{3}, \mathrm{P}_{2} \mathrm{O}_{5}$ phase diagram, which differ by their $\mathrm{Fe} / \mathrm{P}$ ratio value and the clusterisation $\mathrm{n}$ into brackets of the $\mathrm{FeO}_{6}$ octahedra.

The mind idea to keep in mind is that catalysts which exhibit in their structure similar clusterisation of active cation-oxygen anion entities may well be active for a given partial oxidation reaction. This open a large field for discovering new catalysts in the future.

size of the Fe-oxygen clusters $|n|$

1 BARBOSAIITE

|.3) : $100 \%$

$\mathrm{Fe}^{3}+{ }_{2} \mathrm{Fe}^{2+}\left(\mathrm{PO}_{4}\right)_{2}(\mathrm{OH})_{2}$

2 LIPSCOMBITE

$\mathrm{Fe}^{3+}{ }_{2} \mathrm{Fe}^{2+}\left(\mathrm{PO}_{4}\right)_{2}(\mathrm{OH})_{2}$

$[1]: 8 \% \quad[3]: 48 \%$

$[5]: 9 \%[7]: 24 \%$

$3 \mathrm{Fe}^{3}+{ }_{4}\left(\mathrm{PO}_{4}\right)_{3}(\mathrm{OH})_{3}$

$[9]: 3 \%[11]: 6 \%$

[2] : $100 \%$

$4 \mathrm{Fe}^{3+}{ }_{3.87} \mathrm{Fe}^{2+}{ }_{0.38}\left(\mathrm{PO}_{4}\right)_{3}(\mathrm{OH})_{2.62} \mathrm{O}_{0.38} \quad[2: 55 \%[5]: 28 \%$

$5 \mathrm{BFe}^{3}+\mathrm{Fe}^{2}+\left(\mathrm{PO}_{4}\right) \mathrm{O}$

$[8]: 11 \%[1]: 4 \%$

6 OXIDIZED VIVIANITE

$[\infty]: 100 \%$

$\mathrm{Fe}^{3+}{ }_{0.87} \mathrm{Fe}^{2+}{ }_{2.13}\left(\mathrm{PO}_{4}\right)_{2}(\mathrm{OH})_{0.87}, 7.13 \mathrm{H}_{2} \mathrm{O}$

7 ROCKBRIDGEITE

[4] : $100 \%$

$\mathrm{Fe}^{3}+{ }_{4} \mathrm{Fe}^{2+}\left(\mathrm{PO}_{4}\right)_{3}(\mathrm{OH})_{5}$

$8 \mathrm{CsFeP}_{2} \mathrm{O}_{7}$

[1] : $100 \%$

9 INDUSTRIAL CATALYST

$[3]: 100 \%$

$\left(\mathrm{Fe}^{3+}{ }_{2} \mathrm{Fe}^{2+}\left(\mathrm{PO}_{3} \mathrm{OH}\right)_{4}\right)$

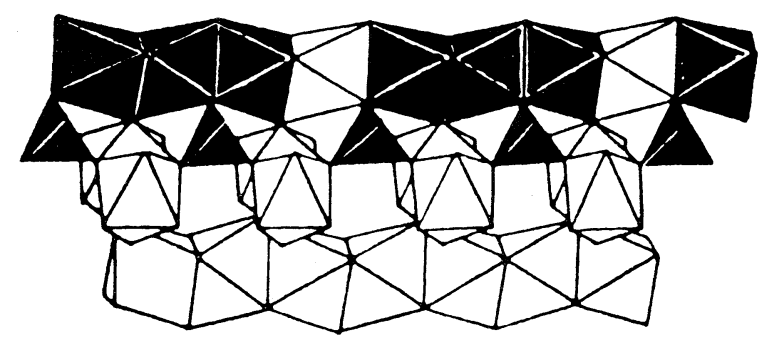

barbosalite

Table 1. Catalysts structural characteristics of some phosphate materials chosen in the $\mathrm{FeO}, \mathrm{Fe}_{2} \mathrm{O}_{3}, \mathrm{P}_{2} \mathrm{O}_{5}$ phase diagram. 
These materials are well known for their lamellar structure and their ability to have their interlayer space enhanced by pillaring and therefore for their potential catalytic interests. For example, vanadium and chromium cations are recognised as good candidates for partial oxidation reactions because of their easy redox properties. These $\mathrm{V}$ and $\mathrm{Cr}$ cations were exchanged (designated $\mathrm{ZrCrP}$ or $\mathrm{ZrVOP}$ ) or, at least deposited by impregnation (designated $\mathrm{Cr} / \mathrm{ZrP}$ or $\mathrm{V} / \mathrm{ZrP}$ ), on the alpha and beta forms of $\mathrm{Zr}\left(\mathrm{HPO}_{4}\right)_{2} .2 \mathrm{H}_{2} \mathrm{O}$ compounds. Their catalytic properties were studied $^{32.33}$ for the oxidative dehydrogenation of ethane to produce ethene and their properties compared to those of bulk $\mathrm{Cr}_{2} \mathrm{O}_{3}, \mathrm{~V}_{2} \mathrm{O}_{5}$, (VO) ${ }_{2} \mathrm{P}_{2} \mathrm{O}_{7}$ and $\mathrm{CrPO}_{4}$ compounds and to $\mathrm{Cr}_{2} \mathrm{O}_{3}$ and $\mathrm{V}_{2} \mathrm{O} 5$ deposited on zirconia and silica supports. The results are reported at $623 \mathrm{~K}$ in table 2 and in fig. 5 vs conversion. It appears clearly that VPO is the best catalyst followed by $\mathrm{CrPO}_{4}$ and $\mathrm{Cr} / \mathrm{alpha} \mathrm{ZrP}$ while all other catalysts, including exchanged ones, are quite poor. Here too, if one considres the cristanite structure of these phosphates, on can conclude that the arrangements of vanadyl and chromyl groups within the bulk phosphate material is determining for their catalytic properties in partial oxidation reactions with respect to the bulk oxides.

\begin{tabular}{|c|c|c|c|c|c|}
\hline \multirow[t]{3}{*}{ Sample } & \multirow{3}{*}{$\begin{array}{l}\mathrm{V} \text { or } \mathrm{Cr} \\
\text { (wt.- } \% \text { ) }\end{array}$} & \multirow{2}{*}{\multicolumn{2}{|c|}{$\begin{array}{l}\text { Conversion } \\
(\%)\end{array}$}} & \multicolumn{2}{|l|}{ Ethylene } \\
\hline & & & & \multirow{2}{*}{$\begin{array}{l}\text { Selectivity } \\
(\%)\end{array}$} & \multirow{2}{*}{$\begin{array}{l}\text { Yield } \\
(\%)\end{array}$} \\
\hline & & Ethane & $\mathrm{O}_{2}$ & & \\
\hline $\mathrm{V}_{2} \mathrm{O}_{5}$ & 56.0 & 1.2 & - & 57 & 0.7 \\
\hline$(\mathrm{VO})_{2} \mathrm{P}_{2} \mathrm{O}_{7}$ & 33.1 & 6.5 & 7 & 80 & 5.2 \\
\hline$\alpha \mathrm{Cr}_{2} \mathrm{O}_{3}$ & 68.4 & 14.8 & 92 & 7 & 1.0 \\
\hline $\mathrm{CrPO}_{4}$ & 33.4 & 25.3 & 76 & 56 & 14.2 \\
\hline $\mathrm{Cr} / \alpha \mathrm{ZrP}(500)$ & 6.7 & 7.6 & 37 & 41 & 3.1 \\
\hline $\mathrm{Cr} / \beta \mathrm{ZrP}(500)$ & 5.9 & 7.3 & 40 & 36 & 2.6 \\
\hline $\mathrm{Cr} / \mathrm{ZrP}_{2} \mathrm{O}_{7}$ & 7.2 & 7.0 & 34 & 34 & 2.4 \\
\hline $\mathrm{Cr} / \mathrm{ZrO}_{2}$ & 6.8 & 12.8 & 86 & 14 & 1.8 \\
\hline $\mathrm{Cr} / \mathrm{SiO}_{2}$ & 5.3 & 15.8 & 87 & 12 & 1.9 \\
\hline
\end{tabular}

Table 2. Catalytic results for supported and bulk $\mathrm{Cr}$ and $\mathrm{V}$ phosphates and oxides in ODH of ethane at $623 \mathrm{~K}$ with $\mathrm{C}_{2} \mathrm{H}_{6}: \mathrm{O}_{2}: \mathrm{N}_{2}=6: 3: 91$ and $100 \mathrm{mg}$ catalysts. 


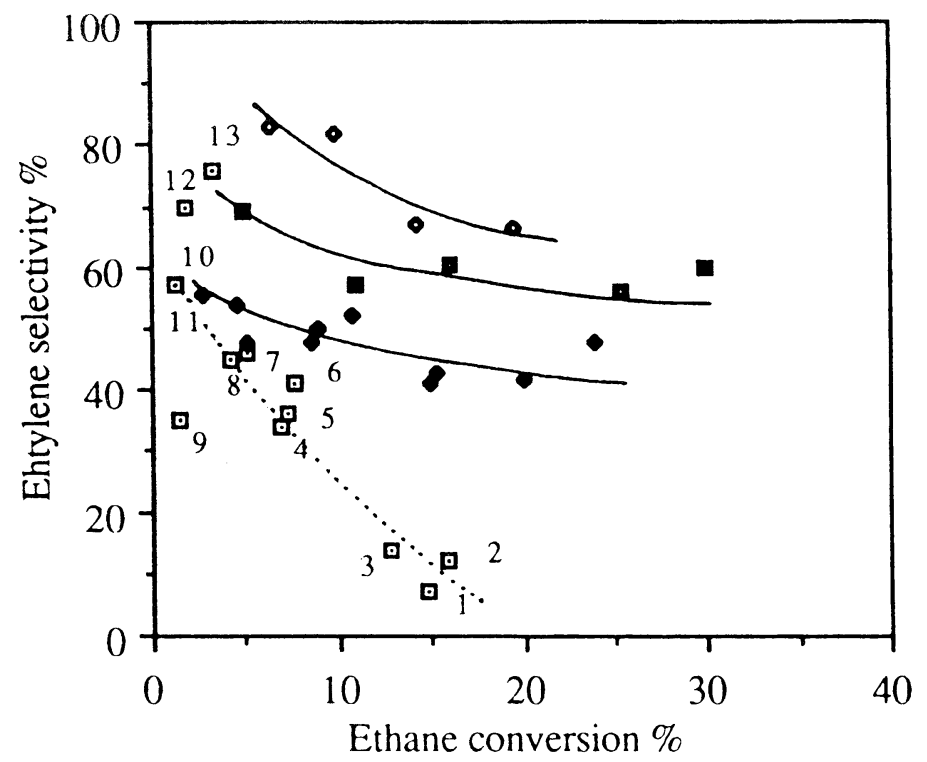

FIGURE 6. Variations of ethene selectivity vs ethane conversion for : $\diamond(\mathrm{VO})_{2} \mathrm{P}_{2} \mathrm{O}_{7}$, - $\mathrm{CrPO}_{4}, \mathrm{Cr} / \mathrm{aZrP}, 1: \mathrm{Cr}_{2} \mathrm{O}_{3}, 2 \mathrm{Cr} / \mathrm{SiO}_{2}, 3 \mathrm{Cr} / \mathrm{ZrO}_{2}, 4 \mathrm{Cr} / \mathrm{ZrP} \mathrm{O}_{7}, 5: \mathrm{Cr} /$ beta ZrP $, 6: \mathrm{Cr} /$ $\mathrm{aZrP}$, 7: Cr/bZrP. 8: aZrCrP, 9: bZrCrP, 1 0: $\mathrm{V}_{2} \mathrm{O}_{5}, \mathbf{1}$ : $\mathrm{Cr} / \mathrm{bZrVOP}$ and 13: bZrVOP.

\section{ALUMINOPHOSPHATES}

This represents another important family in Catalysis. In the early 60ies the $\mathrm{AlPO}_{4}$ material was used as an acid catalyst in many reactions as catalytic cracking. It has been widely replaced by more performing catalysts. It was also used as an acid support for many metals and studied mainly in Córdoba in Spain by the group of Professor Marinas. In the late 70ies, early 80ies the Researchers of Union Carbide, under the guidance if Edith Flanigen ${ }^{34.35}$, at Tarrytown realised that aluminophosphate resembles in many respects silica (cristobalite structure). As silica is the base of a large and important family of molecular sieves, namely the zeolites, they prepare materials of similar structures and they did succeed in synthesising a very large variety of even new structure. It was even possible to replace $\mathrm{P}$ first and then Al from the structure by other elements such as $\mathrm{Si}$ or metallic ion, such as $\mathrm{Co}, \mathrm{Mn}, .$. creating the new families of ElAPO and MeAPO, which exhibit acidic and redox properties (e.g., Si replacing $\mathrm{P}$ may result in the addition of protons for charge balance).

Note that one material, SAPO-34 (S for $\mathrm{Si}$ ), with an erionite structure, may be used industrially in a near future for the conversion of methanol to $\mathrm{C} 2$ and $\mathrm{C} 3$ olefins. Such a reaction, designated as $\mathrm{MTO}$ (methanol to olefins) is of great importance and was mainly studied on strongly dealuminated mordenite and SAPO-34. It necessitates not a too strong acidity (to avoid deactivation by "coking" due to carbonaceous residue deposit) and limited pore size. 
Plenty of other examples may be given, for which metallic phosphates have been studied for their potentialities in heterogeneous catalysis. It is not our purpose to present all of them. We may cite the use of $\mathrm{Cu}$ Nasicon-type phosphates, such as $\mathrm{Cu}_{\mathrm{n}} \mathrm{M}_{2}\left(\mathrm{PO}_{4}\right)_{3}$ with $\mathrm{M}=\mathrm{Zr}$, Sn or Ti and $\mathrm{n}=1$ or $0.5^{36-39}$, the use of $\mathrm{Zr}_{3}\left(\mathrm{PO}_{4}\right)_{4}$ as a support for instance dfor NiMo catalysts for hydrodesulfurisation reaction ${ }^{40}$ or the use of $\mathrm{Mg}$ phosphates for the $\mathrm{N}$-alkylation of aniline with methanol ${ }^{41}$.

\section{REFERENCES}

1 G. Centi, Catal. Today, 16, (1) (1993)

2 J. Johnson, D. Johnson, A. Jacobson and J. Brady, J. Am. Chem. Soc., 106, 8123 (1984)

3 E. Bordes, Catal. Today, 1, 499 (1987)

4 B. Hodnett, Catal. Today, 1, 527 (1987)

5 G. Centi, F. Trifirò, J. Ebner, V. Franchetti, Chem. Rev., 88 , 55 (1988)

6 N. Harrouch Batis, H. Batis, A. Ghorbel, J.C. Védrine and J.-C. Volta, J. Catal., 128, , $248(1991)$

7. E. Lombardo, C. Sánchez and L. Cornaglia, Catal. Today, 15, 407 (1992)

8 F. Trifirò and F. Cavani, Chem. Tech. (1994) 18

9 Z. Ziolkowski, J. Catal., 100, 45 (1986)

10 E. Bordes Stud. Surf. Sci. Catal. , 67, 21 (1991)

11 M.T. Sananes, A. Tuel and J.-C. Volta, J. Catal., 145, 251 (1994)

12 G.J. Hutchings, A. Desmartin-Chomel, R. Ollier and J.-C. Volta, Nature, $\underline{368}, 41$ (1994)

13 Y. Zhang Lin, M. Forissier, R.P.A. Sneeden, J.C. Védrine and J.-C. Volta, J. Catal., $145,256(1994)$

14 P.A. Agashar, L.de Caul and R,K. Grasselli, Catal. Lett., 23, 339 (1994)

15 K.E. Bere, M. Gravelle and M. Abon, J. Chim. Phys., 92, 1521 (1995)

16 G.J. Hutchings, Appl. Catal. , 72, 1 (1991)

17 M.T. Sananès, J.O. Petunchi and E.A. Lombardo, Catal. Today, 15, 527 (1992)

18 F. Ben Abdelouabab, R. Olier, M. Ziyad and J.C. Volta, J. Catal., 157,687 (1995)

19 G.J. Hutchings and R. Higgins, J. Catal. , 162, 153 (1996) 
20 L.M. Cornaglia, C.R. Carrara, J.O. Petunchi and E.A. Lombardo, Appl. Catal. A: General, $\underline{183}, 177$ (1999)

21 J.C. Védrine, J.-M.M. Millet and J.C. Volta, Catal. Today, 32, 115 (1996)

22 J.C. Védrine, G. Coudurier and J.-M.M. Millet, Catal. Today, 33, 3 (1997)

23 J.C. Védrine, Stud. Surf. Sc. Catal., 110, 61 (1997)

24 J.-M.M. Millet, J.C. Védrine and G. Hecquet, Stud Surf. Sc. Catal., 55, 833 (1990)

25 C. Virely, M. Forissier, J.-M.M. Millet and J.C. Védrine, J. Mol. Catal. 71, 199 (1992)

26 D. Rouzies, J.-M.M. Millet, D. Siew Hew Sam and J.V. Védrine, Appl. Catal. A: General, $\underline{124}, 189$ (1995)

27 J.-M.M. Millet, M. Forissier, D. Rouzies, P. Bonnet and J.C. Védrine, Stud. Surf. Sc. Catal., 101, 1011 (1996)

28 V. Robert, S.A. Borshch and B. Bigot, Chem. Phys. Lett., 236, 491 (1995)

29 V. Robert, S.A. Borshch and B. Bigot, J. Phys. Chem., 100, 580 (1 196$)$

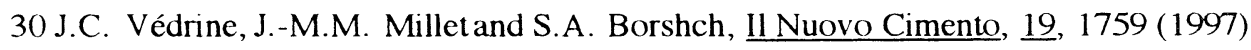

31 P. Bonnet, J.-M.M. Millet, J.C. Védrine and G. Hecquet, Stud. Surf. Sc. Catal., $\underline{82}$, 829 (1994)

32 M. Loukah, G. Coudurier, J.C. Védrine and M. Ziyad, Micropor. Mater., 4, 345 (1995)

33 M. Loukah, G. Coudurier and J.C. Vedrine, Stud. Surf. Sc. Catal., 72, 191 (1992)

34 E.M. Flanigen, B.M. Lok, R.L. Patton and S.T. Wilson, Pure Appl. Chem., 37, 1351 (1986) and references therein

35 B.M. Lok, C.A. Messina,R.L. Patton, R.T. Gajek, T.R. Cannan and E.M. Flanigen, J. Am. Chem. Soc. , 106,6092 (1984)

36 A. Serghini. A. Kacimi, M. Ziyad and R. Brochu, J. Chem. Phys., 85, 499 (1988)

37 A. Serghini, R. Brochu, M. Ziyad, M. Loukah and J.C. Védrine, J. Chem. Soc. Faraday Trans. , 87, 2487 (1991)

38 S. Arsalane, M. M. Ziyad, G. Coudurier and J.C. Védrine, J. Catal., 159, 162 (1996)

39 M. Ziyad, R. Ahmamouch, M. Rouimi, S. Gharbage and J.C. Védrine, Solid State Ionics, 110, 311 (1998)

40 M. Ziyad, M. Rouimi and J.-L. Portefaix, Appl. Catal. A: General, 183, 93 (1999)

41 M.A. Aramendia, V. Borau, C. Jiméne, J.M. Marinas and F.J. Romer, Appl. Catal. A: General, 183, 73 (1999) 